\title{
INTERNET-RESOURCES AS A MEANS OF FUTURE SPECIALISTS' FOREIGN LANGUAGE COMMUNICATIVE COMPETENCE FORMATION
}

\begin{abstract}
у статті обгрунтовано ефективність застосування інтернет-ресурсів у прочесі викладання іноземної мови $з$ метою формування іншомовної комунікативної компетентності майбутнього фрахівия. Поняття іншомовної комунікативної компетентності майбутнього фрахівия детермінується авторами як невід'ємна якість фрахівця сьогодення, професійно-особистісне утворення, сорормоване на основі вмінь та навичок спілкування іноземною мовою з урахуванням культурної приналежності та иінностей кожного учасника діалогу. Здатність мовця використовувати знання з історії, культури, звичаїв і традицій не лише рідної країни, а й країни, мова якої вивчається, вміння вести діалог, слухати співрозмовника й ставити себе на його місце, сприймати та розуміти іншу думку, використовувати професійну чи повсякденну лексику для налагодження міжкультурного діалогу відповідно до комунікативної ситуації, встановлювати певні цілі діалогу та вміння їх досягати - усе це свідчить про високий рівень комунікативноі компетентності фрахівця. Науковці наголошують на тому, що основним показником якості профресійної підготовки майбутнього фахівця $є$ рівень володіння майбутнім фахівчем іноземною мовою з метою ї̈ застосування в майбутній професійній діяльності. Опитування, проведене серед студентів, вказало на доцільність застосування інтернет-ресурсів у прочесі вивчення іноземноі мови для профресійних цілей, зокрема, акцент ставиться на мотиваційній фрункції цих ресурсів. У статті наведено приклад проведення циклу занять для студентів відповідно до навчального плану дисципліни для засвоєння теми з урахуванням інтегративного підходу до ї викладання. Зроблено висновок про те, що використання інтернет-ресурсів під час вивчення іноземної мови для професійних цілей служить не лише засобом модернізації навчання, а й виступає інструментом мотивації до пошуку та вивчення нового, сприяє розвитку вміння відбирати інфрормацію, оцінювання, аналізу та вирішенню іншомовних комунікативних проблем, підвищуе їхній рівень комунікативної культури, мотивує до поваги до комунікативних і поведінкових иінностей, заохочує до самоосвіти та самовдосконалення впродовж життя. Ключові слова: іноземна мова, компетентність, іншомовна комунікативна компетентність, інтернет-ресурси, майбутні фрахівці, профресійна діяльність.
\end{abstract}

The article substantiates the effectiveness of the usage of the Internet resources in the process of foreign language teaching in order to form future specialist's foreign language communicative competence. The authors determine the concept of the future specialist foreign language communicative competence as an integral quality of the present-day specialist, professional and personal education, formed on the basis of the foreign language communication skills, taking into account interlocuters' cultural identity and values as participants of an intercultural dialogue. A speakers ability to use their knowledge of history, culture, customs and traditions of not only their native country but also the country the language of which is studied, an ability to conduct a dialogue, listen to the interlocutor and put themselves in their place, perceive and understand other people's points of view, usage of the professional or everyday vocabulary to establish intercultural dialogue in accordance with the communicative situation, set certain communicative goals and be able to accomplish them - all this certifies a high level of the specialist's communicative competence. The researchers emphasise that the main indicator of the future specialist's qualitative professional training is the level of their foreign language proficiency in order for them to apply this knowledge and skills in the future professional activity. The student survey proved the appropriateness of the online resources application in the process of foreign language for professional purposes learning, in particular, the emphasis is placed on the motivational learning function of these resources. The article demonstrates an example of conducting of a series of classes in accordance with the syllabus for consolidating the topic on the syllabus taking into account the integrative approach to its teaching. It is concluded that the Internet resources usage in the process of the foreign language for professional purposes learning is not only regarded as a means of learning process modernisation, but also serves as a tool for motivation to find and learn, promotes the students' ability to select, evaluate and analyse information, as well as resolve foreign-language communicative situations, enhances their level of communicative culture that motivates respect for communicative and behavioral values, encourages self-education and self-improvement throughout the life. Key words: foreign language, competence, foreign language communicative competence, internet-resources, future specialists, professional activity.
Постановка проблеми в загальному вигляді. Сучасні геополітичні й економічні зміни в розвитку українського суспільства на шляху до приєднання до Європейського Союзу, укладення контрактів про співпрацю між українськими й іноземними підприємцями, активна участь студентів у міжнародних проєктах, програмах для здобуття подвійних дипломів, висока професійна конкуренція як на вітчизняному, так і на міжнародному ринках праці зумовлюють постійно змінні вимоги до професійної підготовки фрахівця. Вищесказане зобов'язує вищі навчальні заклади реагувати на якість професійної підготовки майбутніх спеціалістів, модернізувати навчальні плани та програми вивчення дисциплін.

Мова є інструментом обміну інформацією, взаємодії між людьми, способом передачі почуттів, емоцій учасників міжкультурного та міжнаціонального діалогу. Одним з основних показників якості 
професійної підготовки є рівень володіння майбутнім фрахівцем іноземною мовою з метою її застосування в майбутній професійній діяльності.

Оскільки найпоширенішим джерелом інформації, а також способом проведення дозвілля сучасних студентів сьогодні $€$ інтернет, постає питання раціонального використання інтернет-ресурсів на заняттях, зокрема пошук викладачами методів їх застосування під час викладання навчальних дисциплін. Особливістю інфрормаційних технологій є вільний доступ до необхідної інфрормації, пошук нових знайомств, ознайомлення із краєта країнознавчим матеріалом, перегляд фрільмів, відео, тренінгів, участь у коноеренціях, конкурсах тощо. Тому застосування інтернет-ресурсів для вивчення іноземної мови в аудиторії стає значущим для фрормування професійної іншомовної компетентності майбутнього фрахівця.

Аналіз останніх досліджень і публікацій. Питанням формування професійної іншомовної компетентності майбутнього фрахівця цікавилися такі вітчизняні та закордонні науковці, як: А. Біліченко, Ю. Будас, Д. Демченко, Н. Сорокіна, Н. Костенко, І. Кухта, І. Секрет, Г. Іванчук, М. Bernavskaya, B. Ospanova, T. Timokhina, N. Kassenova, S. Savignon та інші. Застосування інтернет-ресурсів для формування профресійної іншомовної компетентності вивчали Н. Гадайчук, С. Никипорець, Л. Романенко, О. Токменко, О. Шумський. Незважаючи на вагомий внесок перелічених дослідників, проблема фрормування іншомовної комунікативної компетентності залишається актуальною, адже вимоги до виконання професійних завдань на місці праці постійно зростають.

Мета статті - обґрунтування ефективності застосування інтернет-ресурсів для фрормування іншомовної комунікативної компетентності майбутнього фрахівця.

Виклад основного матеріалу. Спершу розглянемо сутність терміна «компетентність». Відповідно до Закону України «Про освіту» («Відомості Верховної Ради України», 2017 р., № № 38-39, ст. 380), компетентність детермінується як «динамічна комбінація знань, умінь, навичок, способів мислення, поглядів, цінностей, інших особистих якостей, що визначає здатність особи успішно соціалізуватися, провадити профресійну та/або подальшу навчальну діяльність» [5]. Отже, наявність компетентності вказує на спроможність особистості реалізуватись у професійній сорері лише завдяки знанням і набутим на практиці вмінням для ефективної подальшої взаємодії з іншими суб'єктами діяльності в певній сорері.

Комунікативний підхід до професійної підготовки фрахівця стає основоположним у закладах вищої освіти. Комунікативна компетентність розглядається як основна якість сучасної людини, пріоритетним завданням якої $€$ вирішення профресійних питань шляхом вербального та невербального спілкування [3]. Здатність мовця використовувати знання з історії, культури, звичаїв та традицій не лише рідної країни, а й країни, мова якої вивчається, уміння вести діалог, слухати співрозмовника й ставити себе на його місце, сприймати та розуміти іншу думку, використовувати професійну чи повсякденну лексику для налагодження міжкультурного діалогу відповідно до комунікативної ситуації, встановлювати певні цілі діалогу та вміння їх досягати - усе це свідчить про високий рівень комунікативної компетентності фахівця.

І. Кухта розглядає іншомовну комунікативну компетентність як «комплекс знань, умінь, навичок, які дозволяють успішно використовувати іноземну мову як у професійній діяльності, так і для самоосвіти й саморозвитку особистості» [3, с. 29]. Н. Костенко, аналізуючи наукові дослідження щодо цього поняття, систематизує його сутність як «здатність установлювати й підтримувати професійні контакти $з$ людьми іншомовного середовища» [4].

Досвід вивчення та викладання іноземної мови, атакожвивчення праць дослідників із цьогопитання дозволяє детермінувати іншомовну професійну компетентність як невід'ємну якість фрахівця сьогодення, професійно-особистісне утворення, сорормоване на основі вмінь і навичок спілкування іноземною мовою з урахуванням культурної приналежності та цінностей кожного учасника діалогу.

Серед пріоритетних інструментів орормування іншомовної комунікативної компетентності вивчення іноземної мови для професійних цілей. 3-поміж основних завдань даної дисципліни фрормування у студентів професійно орієнтованих комунікативних компетенцій для забезпечення іншомовного спілкування у професійному середовищі, практичного розуміння соціокультурних проблем для результативної діяльності в культурному розмаїтті профресійних ситуацій.

У документі «Про Національну стратегію розвитку освіти в Україні на період до 2021 р.» зазначено, що «пріоритетом розвитку освіти є впровадження сучасних інфрормаційно-комунікаційних технологій <...> для забезпечення якості та ефективності освіти, підготовки молодого покоління до життєдіяльності в інфрормаційному суспільстві» [5].

Поширеність, доступність і невід'ємна якість інформаційно-комунікаційних технологій зобов'язують систему вищої освіти інтегрувати ці технології в освітній процес. Безумовно, інтеграція інтернет-ресурсів у навчальну парадигму $€$ досить актуальною сьогодні, адже такі ресурси $€$ безцінними, постійно оновлюються і наповнюються новим змістом для освіти й самоосвіти людей, пошуку нової реальності життя людей та їхній дій у побутових і професійних ситуаціях [6]. Саме завдяки використанню інтернет-ресурсів у навчанні формуються такі практичні вміння іноземної мови: 
- уміння монологічного та діалогічного мовлення шляхом перегляду професійно орієнтованих відео відповідно до ситуації, наближеної до професійної діяльності, програвання певної ситуації через інтерактивні методи навчання (role-plays, presentations, case studies);

- уміння аудіювання завдяки прослуховуванню записів для засвоєння активної тематичної лексики;

- уміння ведення письмової документації за допомогою інтернет-ресурсів, розроблених для вивчення необхідних виразів та кліше;

- уміння аналізувати та вдосконалювати соціокультурні навички 3 метою уникнення міжкультурних конфліктів шляхом перегляду спеціально розроблених відеороликів;

- уміння самостійного вивчення лексичного та граматичного матеріалу, відповідно до рівня студента; уміння самоаналізу та корекції.

Для практичного наведення способів застосування інтернет-ресурсів та фрормування у студентів вищезгаданих умінь покажемо, як можна використовувати різні інтернет-сайти для фрормування іншомовної комунікативної компетентності в аудиторії.

Як приклад візьмемо студентів другого курсу Національного університету «Львівська політехніка» напряму підготовки 291 «Міжнародні відносини, суспільні комунікації та регіональні студії». Відповідно до навчального плану дисципліни «اноземна мова 1, ч. 3», вивчається тема «Проблеми довкілля», виділено 26 годин на аудиторну роботу. Серед умінь, які передбачаються для закріплення, такі:

- уміння монологічного мовлення на теми: довкілля; забруднення довкілля; глобального потепління; природних і техногенних катастроср;

- уміння аудіювання на тему «Зростання населення планети Земля»;

- уміння читання, перекладу і переказу тематичних текстів;

- уміння письмової та усної презентації на одну із запропонованих тем;

- закріплення умінь граматичного матеріалу: неозначені фрорми дієслова: інфрінітив, фрункції інсрінітива в реченні.

Відповідно до плану практичних занять рекомендовано таку навчальну літературу: 1. Д. Турчин. English for International Relations / Англійська мова для міжнародних відносин: навчальний посібник для студентів вищих навчальних закладів. 2-е вид., перероб. і доп. Вінниця: Нова Книга, 2011. 256 c. 2. Pilbeam A. Market Leader: Working Across Cultures. Pearson, Longman Education Limited, 2010. 96 p.

Аудиторні заняття 3 метою вивчення теми проводились у групі із 12 студентів, серед яких 8 студентів володіють англійською мовою на рівні В1 та 4 - В2, згідно із Загальноєвропейськими рекомендаціями мовної освіти. 3 метою уріз- номанітнення загальної методики навчання та мотивації студентів до кращого засвоєння матеріалу, а також вивчення іноземної мови було проведено опитування серед студентів для визначення доцільності застосування інтернет-ресурсів на заняттях. Серед запропонованих питань анкетування були такі: Чи вважаєте інфрормаційну мережу інтернет інструментом для вивчення іноземної мови?; Чи доцільним є застосування інтернет-ресурсів в аудиторії?; Чи мотивуватиме Вас застосування інтернет-ресурсів в аудиторії? 83\% респондентів підтримали цю ініціативу та наголосили на зацікавленні щодо інтернет-ресурсів, тоді як 2 студентів вагались через нижчий рівень володіння мовою.

Не відходячи від програми та поставлених завдань, з метою якісної підготовки до складання кредиту з дисципліни й урахуванням уподобань студентів заняття проводились так:

Тема: Проблеми довкілля. Enviromental Issues:

1. Lead-in stage: Comment on the following: 1, 2, 3.

2. Pre-reading stage; Essential vocabulary on the topic: a table with the new words (a word - a definition - a translation).

3. Reading stage: Read the text (there are usually more than one text) and then mark the following statements as true or false.

4. Post-reading stage: do the following exercises for the vocabulary consolidation.

5. Essential grammar: do the following exercises on Infinitive.

Тут, відповідно до рівня володіння студентом іноземною мовою, крім вправ із підручників, запропонованих навчальним планом, використовувались вправи із сайту: https://www.englishtestsonline. com/english-grammar-tests/intermediate/; https://www.englishtestsonline.com/englishgrammar-tests/upper-intermediate-englishgrammar-tests/. Вибір даного сайту зумовлений диференційованим підходом до укладання вправ, наявністю варіантів відповідей на вибір, що стимулює студентів до аналізу інформації, а також наявністю підказок у разі неправильної відповіді. Наведемоприкладщеодноговебсайтудлявивчення граматики з урахуванням диференційованого підходу: www.engvid.com/englishgrammar/. Студентам рекомендовано перегляд відео із граматики в рамках самостійної роботи та виконання тесту з його завершення.

6. Pre-listening stage: read the following statements and comment on them.

7. Listening stage: Listen to the recording and do the following exercises: choose the correct answer; listen again and fill in the gaps.

8. Post-listening stage: the students are divided into pairs or groups and act out a conversation based on the recording:

Student A: You are calling from $<\ldots>$.

Student B: You work for <...> (or more students). 
Доповненням на цьому етапі за вибором студентів служить інтернет-програма для вивчення іноземної мови ВВC Learning English. Студенти віддають перевагу цій програмі, оскільки укладачі постійно оновлюють її змістове наповнення, зокрема різні теми для обговорення секції 6 Minute English. Ведучі не лише обговорюють якусь тему, а й виокремлюють зазвичай шість тематичних слів чи виразів, дають їм визначення та презентують їх уживання в комунікативній ситуації. Для кращого ознайомлення з повсякденною лексикою рекомендуємо секцію The English We speak. Кожне нове повідомлення містить одну срразу чи ідіому для обговорення. Наприклад, Talk the talk чи Out with the old, in with the new, яка обговорюється ведучими для кращого її сприйняття та розуміння.

9. Video watching stage.

На цьому етапі продовження вивчення теми "Environmental Issues" заслуговує на увагу ще один вейсайт: www.tedtalks.com/education. Варто зазначити, що для студентів із вищим рівнем володіння англійською мовою перегляд відео проводиться без субтитрів, на відміну від слабших студентів. Відео "А creative approach to climate change" доповнювалось розробленими викладачем вправами для кращого засвоєння лексики та матеріалу загалом на зразок: 1. Answer the following questions on the video. 2. Fill in the gaps. 3. Insert the appropriate prepositions. 4. Translate the sentences into Ukrainian.

10. Speaking stage. Express your point of view: answer and discuss the following questions. Do research if necessary. Hold a debate within your group. Use phrases for debating. Пропонувалось використання певних вебсайтів для вивчення сталих виразів і кліше для проведення дебатів, зокрема: https://www.myenglishteacher.eu/blog/category/ learn-english/. Цей сайт вирізняється своєю доступністю, а також у секції Speaking можна ознайомитися з культурознавчими аспектами вивчення іноземної мови з метою уникнення міжкультурних непорозумінь.

11. Writing stage. Write a report on the latest domestic or world news.

Для виконання цього завдання студенти відвідують такі вебсайти, як www.euronews.com, або інтернет-програму BBC Learning English, зокрема секції News Report, News review, Words in the news.

На цьому етапі можна запропонувати студентам зробити презентацію, наприклад, на тему: Humankind will be able to solve the environmental issues in the nearest future. The ways we propose are the following $<\ldots>$. Для виконання цього завдання варто переглянути відео для кращого розуміння сталих виразів і етапів проведення презентації на сайті www.youtube/presentationbeginnings/ Joshua Durey. Автор представляє низку відео із субтитрами, а також дає досить чіткі рекомендації для ефективного проведення презентації.
Отже, використання інтернет-ресурсів під час вивчення іноземної мови для професійних цілей служить не тільки засобом модернізації навчання, а й інструментом мотивації до пошуку та вивчення нового, сприяє розвитку вміння відбирати інорормацію, оцінювання, аналізу та вирішення іншомовних комунікативних проблем, підвищує їхній рівень комунікативної культури, мотивує до поваги до комунікативних і поведінкових цінностей, заохочує до самоосвіти та самовдосконалення впродовж життя.

Висновки. На основі вищесказаного можна зробити висновок, що використання інтернетресурсів в аудиторії $\epsilon$ якісним доповненням навчального процесу з метою його модернізації, інструментом для мотивації студентів до використання цього ресурсу не лише з розважальною, а й з освітньою метою. Проте зазначимо, що в освітньому процесі інтернет не можна розглядати як основний компонент навчання, а лише як додатковий складник за вибором та чітким контролем викладача для досягнення навчальних цілей.

До напрямів подальшого дослідження відносимо створення інтернет-платсрорм для науковопедагогічних працівників у системі вищої та післядипломної освіти 3 метою співпраці з роботодавцями, виявлення актуальних проблем у профресійній діяльності для їх подальшого опрацювання та модернізації змістового наповнення дисциплін.

\section{БІБЛІОГРАФІЧНИЙ СПИСОК:}

1. Bimaganbetova K. Formation of foreign language professional communicative competence of a future expert. In AWER Procedia Information Technology \& Computer Science / B. Tabyldieva et al. 2013. № 04. P. 1134-1139. URL: www.awer-center.org/pitcs.

2. Про освіту : Закон України. Відомості Верховної Ради України. 2017. № № 38-39. Ст. 380. URL: https://zakon.rada.gov.ua/laws/show/2145-19.

3. Костенко Н. Особливості фрормування іншомовної комунікативної компетентності у студентів ВН3 несрілологічних спеціальностей. Збірник наукових праць Хмельницького інституту соціальних технологій Університету «Україна». 2012. № 5. С. 86-89. URL: http://nbuv.gov.ua/UJRN/Znpkhist_2012_5_21.

4. Кухта І. Іншомовна компетентність у контексті фрормування комунікативної культури студентів у процесі вивчення іноземної мови/ Вісник Вінницького політехнічного інституту. 2010. № 4. C. 27-32. URL: https://visnyk.vntu.edu.ua/index. php/visnyk/article/view/613/612.

5. Про Національну стратегію розвитку освіти в Україні на період до 2021 р. URL: https://zakon.rada.gov.ua/laws/show/344/2013.

6. Тарасова С. Інтернет-мем як креативний навчальний інструмент візуалізації. Методичні та психолого-педагогічні проблеми викладання іноземних мов на сучасному етапі: шляхи інтеграції школи ma BH3 : матеріали XI Міжнародної науково-методичної консреренції, м. Харків, 18 квітня 2019 р. М-во освіти і науки України, Харківський національний університет імені В.Н. Каразіна. Харків, 2019. С. 153-155. 